\title{
UC Merced Center for Computational Biology
}

\author{
Final Report
}

November 30, 2010

DOE Award: \#DE-FG02-04ER25625

Award Period: 9/1/2004 through 8/31/2010

Principal Investigator:

Dr. Michael Colvin, Professor

School of Natural Sciences

University of California

5200 N. Lake Rd., Merced, CA 95343

Email: mcolvin@ucmerced.edu

Phone: 209-228-4364 Fax: 209-228-4053

Co-PI and Academic Coordinator:

Dr. Masakatsu Watanabe, Director of Student Success

School of Natural Sciences

University of California

5200 N. Lake Rd., Merced, CA 95343

Email: mwatanabe@ucmerced.edu

Phone: 209-228-3037 Fax: 209-228-4053

Co-Investigators:

- Prof. Arnold D. Kim, School of Natural Sciences, University of California, Merced

- Prof. Maria Pallavicini, School of Natural Sciences, University of California, Merced

- Dr. Felice Lightstone, Physical and Life Sciences Directorate, Lawrence Livermore National Laboratory 


\section{Executive Summary}

The Center for Computational Biology (CCB) was established to support multidisciplinary scientific research and academic programs in computational biology at the new University of California campus in Merced. In 2003, the growing gap between biology research and education was documented in a report from the National Academy of Sciences, Bio2010 Transforming Undergraduate Education for Future Research Biologists. We believed that a new type of biological sciences undergraduate and graduate programs that emphasized biological concepts and considered biology as an information science would have a dramatic impact in enabling the transformation of biology. UC Merced as newest UC campus and the first new U.S. research university of the $21^{\text {st }}$ century was ideally suited to adopt an alternate strategy - to create a new Biological Sciences majors and graduate group that incorporated the strong computational and mathematical vision articulated in the Bio2010 report. CCB aimed to leverage this strong commitment at UC Merced to develop a new educational program based on the principle of biology as a quantitative, model-driven science. Also we expected that the center would be enable the dissemination of computational biology course materials to other university and feeder institutions, and foster research projects that exemplify a mathematical and computationsbased approach to the life sciences. As this report describes, the CCB has been successful in achieving these goals, and multidisciplinary computational biology is now an integral part of UC Merced undergraduate, graduate and research programs in the life sciences.

The CCB began in fall 2004 with the aid of an award from U.S. Department of Energy (DOE), under its Genomes to Life program of support for the development of research and educational infrastructure in the modern biological sciences. This report to DOE describes the research and academic programs made possible by the CCB from its inception until August, 2010, at the end of the final extension. Although DOE support for the center ended in August 2010, the CCB will continue to exist and support its original objectives. The research and academic programs fostered by the CCB have led to additional extramural funding from other agencies, and we anticipate that CCB will continue to provide support for quantitative and computational biology program at UC Merced for many years to come.

Since its inception in fall 2004, CCB research projects have continuously had a multi-institutional collaboration with Lawrence Livermore National Laboratory (LLNL), and the National Center for Supercomputing Applications at the University of Illinois at Urbana-Champaign, as well as individual collaborators at other sites. CCB affiliated faculty cover a broad range of computational and mathematical research including molecular modeling, cell biology, applied math, evolutional biology, bioinformatics, etc. The CCB sponsored the first distinguished speaker series at UC Merced, which had an important role is spreading the word about the computational biology emphasis at this new campus.

One of CCB's original goals is to help train a new generation of biologists who bridge the gap between the computational and life sciences. To archive this goal, by summer 2006, a new program - summer undergraduate internship program, have been established under CCB to train the highly mathematical and computationally intensive Biological Science researchers. By the end of summer 2010, 44 undergraduate students had gone through this program. Out of those participants, 11 students have been admitted to graduate schools and 10 more students are interested in pursuing graduate studies in the sciences. The center is also continuing to facilitate the development and dissemination of undergraduate and graduate course materials based on the latest research in computational biology. 


\section{Table of Contents}

I. CENTER FOR COMPUTATIONAL BIOLOGY .......................................................4

A. CCB AFFILIATED FACULTY MEMBERS AND RESEARCHERS .............................................. 4

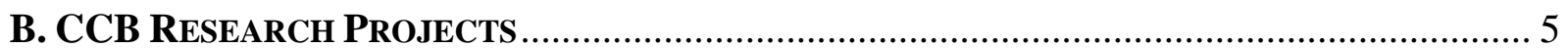

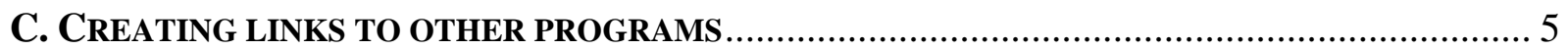

II. BIOLOGY CURRICULA AND COURSE MATERIALS .................................................. 5

A. UNDERGRADUATE COURSE AND CURRICULUM DEVELOPMENT: .................................. 6

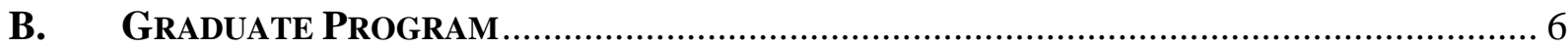

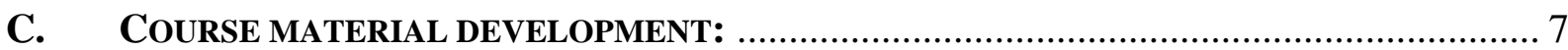

D. DISSEMINATION OF CCB COURSE MATERIALS TO OTHER INSTITUTIONS: ……............. 8

III. STUDENT RESEARCH PROGRAMS IN COMPUTATIONAL BIOLOGY ............. 9

A. UNDERgRAdUATE SUMMER INTERNSHIP PROGRAM ………......................................... 9

B. COMPUTATIONAL BIOLOGY PROGRAM FOR BIOLOGY EDUCATORS ................................. 11

IV. CONTINUATION OF THE CCB INTO THE FUTURE............................................ 11

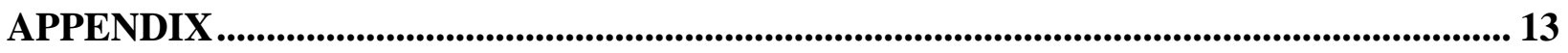

I - CCB AFFILIATED FACULTY. ................................................................................. 13

II - CCB SUMMER RESEARCH INTERNSHIP PROGRAM PARTICIPANTS .................................. 15

III - CCB UNDERGRADUATE RESEARCH ASSOCIATES.................................................... 16

IV - CCB GRADUATE RESEARCH ASSOCIATES .............................................................. 16

V - AFFILIATED RESEARCHER AND PoST-DOCTORAL FELLOWS .......................................... 17

VI - CCB PUBLICATIONS BETWEEN 2006 AND 2010 ………............................................ 18

VII - LIST OF CCB DISTINGUISHED SPEAKERS 18 


\section{Introduction}

The Center for Computational Biology (CCB), which was established at the newest campus of the University of California in fall, 2004, has been responsible for new research projects, seminar series, graduate and undergraduate academic program development and student workshops, all with the goal of producing life scientists with strong quantitative and computational skills. The role of the center in developing new programs for UC Merced, and in the aspirations that the campus had for itself, was highlighted in the convocation speech by UC Merced founding Chancellor Tomlinson-Keasey on September 5, 2005:

"Our Center for Computational Biology, led by Michael Colvin, builds on the important relationship between computers and biology. The human genome was sequenced in record time because computer scientists and biologists worked together. Our Center will exploit this synergy to understand more about biological systems. Federal grants constitute an amazing percentage of the University's budget and these grants help propel ideas."

As these words described, since the beginning, the center has been a central element in the development of research and academic programs in computational and mathematical biology at the new university. This project had three core goals that aim to recast teaching and research in biology as an information science:

I. Develop a Center for Computational Biology to host multidisciplinary research projects in computational and mathematical biology that will provide a rich environment for graduate and undergraduate research.

II. Develop computational biology curricula and course materials that can be used to introduce quantitative and computational concepts into undergraduate courses that would usually not include such topics. Additionally, these materials will be made available to colleges and universities that want to introduce computational biology into their curricula.

III. Develop and support undergraduate research programs in computational biology that integrate quantitative and computational concepts throughout the undergraduate and graduate coursework and provide research opportunities in computational biology for students at all levels.

The remainder of this section presents the CCB accomplishments for the overarching goals listed above.

\section{Development of the Center for Computational Biology}

\section{A. CCB Affiliated faculty members and researchers}

The Center for Computational Biology is currently the largest cross-disciplinary center at UC Merced and has been playing an important role in shaping research and educational planning on the campus since its start. CCB members are involved in curriculum planning for the graduate and undergraduate programs and recruitment for new faculty in biology, mathematics and 
computer science. The CCB has been a major facilitator of cross-disciplinary research at UC Merced, starting with workshops and meetings with UC Merced faculty and LLNL researchers to identify promising collaborative projects, and then sponsoring graduate students, post-docs and faculty to foster these research projects. As a result, UC Merced has developed a robust crossdisciplinary culture in computational biology, with productive, ongoing collaborations, between faculty in biology, applied mathematics, biophysics and computer science. Currently, a total of seventeen faculty or staff are affiliated to the CCB. (See the details in Appendix I).

\section{B. CCB Research Projects}

Since its inception in fall 2004, the CCB has been actively promoting multidisciplinary research projects, which were chosen to link mathematical and computational sciences with "real-world" biological problems. Brief descriptions of funded research projects and researchers are listed in Appendix: Undergraduate research projects are listed in Appendix III, Graduate research project in Appendix IV, and Postdoctoral research projects in Appendix V. Additionally, publications of CCB funded projects is listed in Appendix VI. These CCB projects have provided the starting point for several projects that developed into independently funded multidisciplinary research projects. It is significant that the majority of UC Merced faculty supported by the CCB are at the Assistant Professor level. Multidisciplinary research is sometimes considered risky for pretenure faculty because such projects are logistically complex and can prove difficult to fund before promising initial results are achieved. The CCB has been successful in helping UC Merced junior faculty to establish multidisciplinary research projects that in several cases have already led to additional outside research funding.

\section{Creating links to other programs}

A challenge to a new research program, especially at a brand new university campus, is to create visibility within the larger research community. To this end, the CCB sponsored UC Merced's first distinguished speaker series that brought in 19 visiting speakers in the area of computational biology from established programs at institutions including UC Berkeley, Harvard University, Caltech, and Oak Ridge National Laboratory. (Full lists of speakers can be found in Appendix VII) These seminars were important in making the research community aware of the computational biology emphasis at UC Merced and also provided UC Merced faculty and students access to a broader range of research ideas than available on our initially small campus. The success of this speaker series helped convince the UC Merced administration to provide continuing support for a speaker series within the Quantitative and Systems Biology Graduate Group.

\section{Development and Dissemination of Biology course materials}

In order to support the development of UC Merced's life sciences curriculum that is strongly oriented towards quantitative skills, including mathematics and computing, the CCB has been instrumental to develop innovative computational courseware to teach these concepts. Course materials and laboratories developed by the CCB have continued to be used though out the UC Merced life sciences curriculum since fall 2005. As the number of computationally sophisticated life sciences students at UC Merced has increased, we have been assisting in developing course materials and infrastructure for more advanced computational biology courses and workshops. 
CCB faculty and staff have successfully developed and been providing new capstone courses in computational biology for life science majors. Additionally, CCB faculty and staff have also developed an extensive set of lecture materials and laboratories for running molecular simulations on high performance computers. These course materials have been used in the CCB summer undergraduate research internship programs (see below) and disseminated to other life sciences and computer science programs.

A. Undergraduate course and curriculum development: As described in the original proposal, the biology academic programs at UC Merced were developed to emphasize quantitative and computational biology. To this end, CCB faculty and staff worked to develop the original curricula to include upper division computational biology courses as well as prerequisite courses in computational skill and statistics to enable success in these courses. This innovative biology program has been very successful and is the largest undergraduate major at UC Merced (more than twice the size of the next most popular major), with 979 majors as of fall, 2010. Additionally, these computational and quantitative biology courses are taken by students in several other majors, including Applied Mathematics, Bioengineering, and Physics. CCB faculty and staff provided the expertise, technical support and facilities to enable the core undergraduate computational biology courses:

- Introduction to Scientific Data Analysis for Life Science majors (Math 15) Fundamental analytical and computational skills to find, assemble and evaluate information, and to teach the basics of data analysis and modeling using spreadsheets, statistical tool, scripting languages, and high-level mathematical languages.

- Mathematical Modeling for Biology (BIO 180) - Statistical analysis and mathematical modeling skills for life scientists. The first half of this course is about building statistical models of complex data sets and the second half is about using population models to describe demographic change, ecosystems and epidemics. Extensive computer laboratories using the " $R$ " statistical language.

- Introduction to Biomolecular Simulation (BIO 181) - Lectures and laboratory exercises teach the principles and practice of molecular modeling with a focus on simulations of biological macromolecules. Topics covered include classical molecular dynamics, molecular mechanics, docking, and visualization. The computational laboratories involve simulations of systems including water, micelles, DNA, and proteins.

- Bioinformatics (BIO 182) - Detailed introduction to the tools, algorithms, statistics and databases used in bioinformatics, emphasizing an open-source, command line toolbox approach.

\section{B. Graduate Program}

The CCB has been involved in shaping the graduate biology and mathematics programs at UC Merced. This program has supported collaborative projects involving graduate students from three graduate groups at UC Merced: Applied Math, Computer Science and Engineering, and Quantitative and Systems Biology. The CCB has also organized meetings that brought together faculty from all three of these graduate groups to discuss multidisciplinary projects in 
computational and mathematical biology. (See Appendix IV for details of funded projects for CCB affiliated graduate students.)

Additionally, three of the courses described BIO 180, BIO 181, and BIO 182, were also developed and delivered as graduate courses within the UC Merced Quantitative and Systems Biology Graduate Group, which is currently the largest Ph.D. program at UC Merced. This graduate program has already graduated twelve doctoral students, nearly all of whom have taken one or more of these computational biology graduate courses.

C. Course material development: In addition to supporting the development of the computational biology courses described above, the CCB developed quantitative and computational biology course modules and lab activities that were used in several of the largest enrollment undergraduate biology courses at UC Merced. This ensured that all life sciences students at UC Merced got early exposure to the tools and concepts of computational biology.

- Computational assignments for BIO 1 (Contemporary Biology) \& BIO 3

(Molecular Basis of Health and Disease) Some of these materials are now available at http://ccb.ucmerced.edu/materials.html

- Molecular visualization

- Phylogenetic trees

- Allele frequencies

- Population dynamics

- Computer Lab manuals and materials for upper division biological science courses:

- BIO 110 (The Cell)

- Modeling of biological molecules

- Simulation of Signal transduction

- BIO 141 (Evolution)

- Introduction to UNIX

- Introduction to BLAST (Sequence analysis)

- Game Theory

$\circ \quad$ Allele Frequencies 


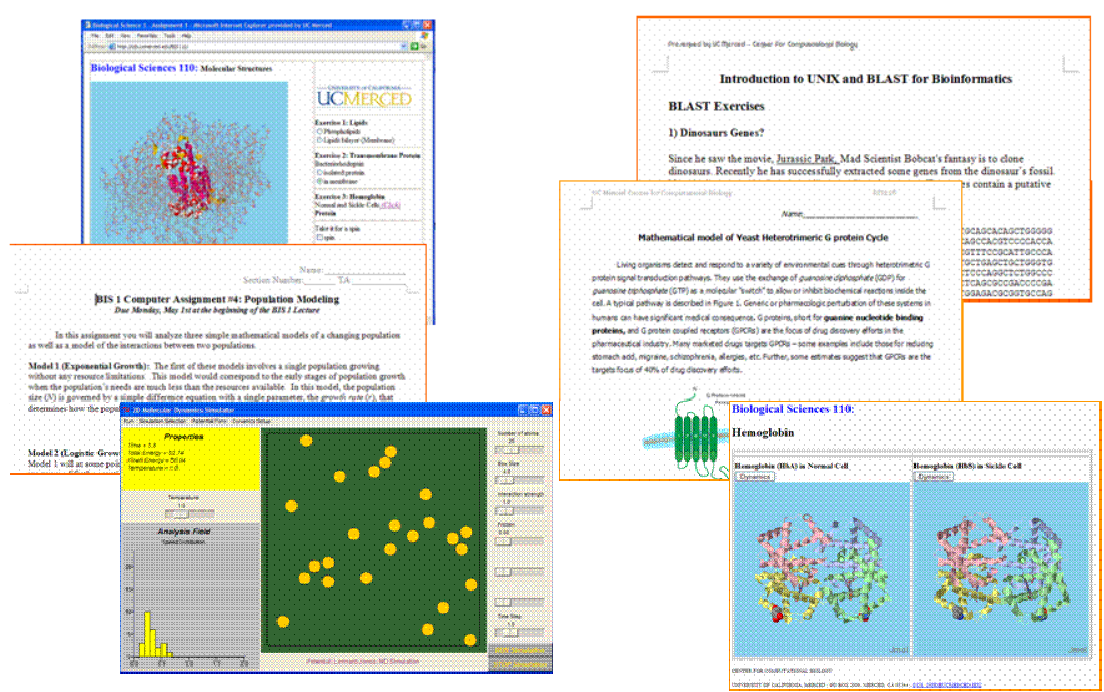

Figure 1 Examples: Developed Course materials

\section{Dissemination of CCB course materials to other institutions:}

We are making all course materials developed by the CCB available in several ways:

- We have been working to deposit our educational materials in the National Science Digital Library (NSDL) -Computational Science Education Reference Desk (CSERD) to facilitate the incorporation of more quantitative and computational teaching into contemporary biology education.

- Based on requests from faculty at a number of California Community Colleges to use CCB materials in their biology courses, we are revising the CCB website to include a more complete sets of laboratory materials and associated lecture materials. These will be available at http://ccb.ucmerced.edu/resources.html.

- We have also converted a portion of our computational biology materials to be freely distributed using the Connexions Courseware System developed at Rice University (fully described at the URL: http://cnx.rice.edu).

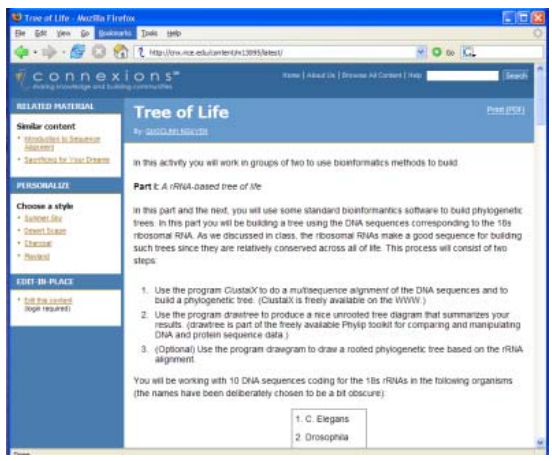

Figure 2 Example Connexions Course Module of BIO 1's Phylogenetic Analysis. (Available at http://cnx.rice.edu/content/m13095/) 
- Based on personal requests we have distributed our computational biology teaching materials to faculty at a number of universities including the University of Illinois at Urbana-Champaign, Fresno State University, Humboldt State University, Shodor (a national resource for computational science education).

\section{Student research programs in computational biology}

\section{A. Undergraduate Summer Internship Program}

CCB's six-week undergraduate summer program was developed to provide undergraduate students at UC Merced with hands-on research experience in computational biology. This was the first undergraduate summer research program at UC Merced and continues to be the largest such program. In the five summers that this program has been offered (2006-2010), a total of 44 undergraduate students (mostly either sophomore or junior standing students), from diverse academic backgrounds have participated. Full lists of former summer program participants can be found in Appendix II. Since one goal of the program was to increase the diversity of students entering computational biology, it is notable that more than $65 \%$ of participants were female and $14 \%$ of the participants were African-American or Hispanic.

In the past three years, this program focused on molecular dynamics simulations and its applications. The following topics are be covered each week during the six-week program:

1. Introduction to Molecular Dynamics Simulation

2. Applications to Aqueous systems

3. Applications to Protein and Protein design

4. Applications to DNA

5. Applications to Carbon Nanostructures

These students have learned in detail the GROMACS molecular dynamics program suite and gain experience in many aspects of high performance scientific computing, including use of the Linux operating system, supercomputing resources, queuing systems, etc. For this program we have been awarded an allocation (30,000 units for 2008 and 70,000 units for 2009) of supercomputer time on TeraGrid Supercomputers and all students had individual accounts on large Linux clusters at the Texas Advanced Computing Center and the NCSA.

In all except the final year (2010), the CCB Undergraduate Summer Program culminated with a week-long visits either a national laboratory and supercomputer center to broaden the student's knowledge about computational biology and research opportunities. In 2006 and 2008, we visited National Center for Supercomputing Research (NCSA) at University of Illinois, UrbanaChampaign; In 2007, we visited the Oak Ridge National Laboratory and in 2009, the San Diego Supercomputer Center. There, students learned about and shared new ideas, materials, and tools for integrating mathematics and physical sciences with biology through computational tools and resources. In each case, at the end of the week the students presented their research results at mini-symposia to local faculty and staff. 
Table 1 Ethnicities and genders represented by UC Merced Center for Computational Biology Summer internship program between 2006 and 2010.

\begin{tabular}{|c|c|c|c|c|c|c|}
\hline & 2006 & 2007 & 2008 & 2009 & 2010 & Total \\
\hline Total \# of Participants & 7 & 8 & 9 & 9 & 11 & 44 \\
\hline \multicolumn{7}{|l|}{ Ethnicity } \\
\hline Black, non-Hispanic & 1 & & & & & 1 \\
\hline \multicolumn{7}{|l|}{ American Indian/Alaskan Native } \\
\hline Asian/Pacific Islander & 2 & 1 & 3 & 6 & 4 & 16 \\
\hline Hispanic & & 2 & 2 & & 1 & 5 \\
\hline White, non-Hispanic & 2 & 4 & 4 & 3 & 6 & 19 \\
\hline Other/Unknown & 2 & 1 & & & & 3 \\
\hline \multicolumn{7}{|l|}{ Non-resident Foreign } \\
\hline \multicolumn{7}{|l|}{ Gender } \\
\hline Male & 2 & 1 & 2 & 5 & 4 & 14 \\
\hline Female & 5 & 7 & 7 & 4 & 7 & 30 \\
\hline
\end{tabular}

In addition to facilitate an undergraduate research experience, one of other goals of the summer program was to increase the numbers and diversity of students successfully continuing in quantitative and computational biology research careers by pursing their graduate education opportunities. Table 2 lists program participants who have began their graduate studies in science. We have been successfully promoting our undergraduate students to the next level.

Table 2 List of summer program participants who pursue graduate degrees. Note that all of 2009 and 2010 cohorts are currently still undergraduate students, and a majority of those have expressed interest in pursuing graduate studies.

\begin{tabular}{|c|c|c|c|}
\hline Last Name & First Name & Graduate School & Program \\
\hline \multicolumn{4}{|c|}{2008 Cohort } \\
\hline Rodriguez & Jo-Anne & University of Maryland & Pharmaceutical Sciences \\
\hline Orrell & Heather & UC Merced & Bioengineering \\
\hline Koobatian & Max & SUNY & Physiology \\
\hline Lor & Chai & UC Merced & Bioengineering \\
\hline Lau & Chi Ying & UC San Diego & Bioengineering \\
\hline \multicolumn{4}{|c|}{2007 Cohort } \\
\hline Montoy & Sarah & CSU Fresno & Forensic Science \\
\hline Swendsen & Haruka & $\mathrm{NIH}$ & Postgraduate follow \\
\hline St. Clair & William & UC Merced & Cognitive Science \\
\hline \multicolumn{4}{|c|}{2006 Cohort } \\
\hline Vue & Zer & UC Merced & Quantitative Biology \\
\hline Bhardwaj & Ritu & CSU East Bay & Biology \\
\hline Alilin & Alaena & UC Merced & Applied Math \\
\hline
\end{tabular}




\section{B. Computational Biology program for Biology Educators}

In addition to graduate and under graduation programs, in collaboration with SC Education program (http://sc09.sc-education.org/) and the iPlant Collaborative (http://www.iplantcollaborative.org/), the UCM-CCB organized the Computational Biology for Biology Educators workshop in summer 2009. This workshop introduced college faculty to various resources that can be used to prepare students to acquire computational thinking, modeling and quantitative analysis skills that have become essential to the practice of modern biology. Hands-on sessions with software for building and running dynamic models, finding sequence motifs, inferring phylogeny and predicting structure will be coupled with pedagogy and examples of integration into the biology classroom. 17 faculty and educators from the US and one faculty from Mexico participated in this workshop.

\section{Continuation of the CCB into the future}

Since its foundation in fall 2004, the CCB has been successful in integrating computational mathematical concepts into the research and academic programs at UC Merced, and we believe that this builds the foundation for many future multidisciplinary research projects and has started to create a cohort of life sciences students with strong computational and simulation skills. Moreover, many of the undergraduate students who have participated in CCB research activities have moved on to graduate studies in diverse scientific disciplines, including applied math, computational biology and bioengineering, and UC Merced graduate students who have participated in CCB research projects and computational biology courses and moved on to postdocs and research positions, bringing with them the quantitative and computational approach to biology they have learned in CCB-enabled courses and research projects.

During the last few years of the program, we have been focusing on strategies to sustain research and academic programs fostered by the CCB. We have applied for and been awarded a five-year grant from the National Science Foundation to continue the innovative academic and summer programs that introduce undergraduate students to the concepts and tools of computational biology. This new NSF project, entitled Undergraduate Mentoring Program for biological sciences - undergraduate research in Computational Biology will replace and expand the CCB computational biology summer internship program by providing three new components: (1) a summer training program; (2) two years of independent research, mentored directly by faculty, and culminating in a research portfolio; and (3) ongoing enhancement activities to foster cohortbuilding and networking, peer mentoring, communication and writing skills building, ethics training, and career development. This program will ensure that undergraduate research in computational biology will continue to be a signature element of UC Merced.

Additionally, a number of the multidisciplinary computational biology projects fostered by the CCB have been successful in growing into independently funded research programs. To cite one example, a collaboration between biologists, computer scientists, and biophysicists at UC Merced that began as a CCB seed project, was just awarded a large 3-year NSF Advances in Biological Informatics grant to develop new computational tools for characterizing intrinsically disordered proteins. 
Finally, the most significant and long-lasting impact of the CCB has been that it has established computational biology as a central theme of the University of California at Merced, that is reflected in nearly all aspects of its life sciences programs. Computational biology is built into Biological Sciences undergraduate major and the life science graduate group (even in the graduate group name: Quantitative and Systems Biology). This emphasis also influenced the types of life sciences faculty recruited (and helped attract excellent faculty to UC Merced), and has helped establish multidisciplinary, quantitatively focused biology research as a signature theme of this campus. The success and popularity of the academic and research programs in computational and quantitative biology promise that this will continue to be a recognized strength as UC Merced grows into a full-sized UC campus over the coming decades. 


\section{Appendix}

I - CCB Affiliated Faculty This table lists all UC Merced faculty who received CCB support for their summer salary or for graduates students in their research groups, who participated in a CCB-supported scientific collaboration, or received CCB support of computational biology course materials. Note that 10 of the 15 UC Merced faculty are Assistant Professors.

\begin{tabular}{|c|c|c|c|}
\hline & Faculty Name & School & Research Interest \\
\hline 1 & $\begin{array}{l}\text { Prof. Michael Colvin } \\
\text { (Ph.D. UC Berkeley) }\end{array}$ & $\begin{array}{l}\text { School of Natural } \\
\text { Sciences, UC Merced }\end{array}$ & $\begin{array}{l}\text { Computational Biologist who applies } \\
\text { mathematical and computational methods to } \\
\text { systems ranging from biomolecules up to } \\
\text { cell populations. }\end{array}$ \\
\hline 2 & $\begin{array}{l}\text { Asso. Prof. Arnold Kim } \\
\text { (Ph.D. Univ Washington) }\end{array}$ & $\begin{array}{l}\text { School of Natural } \\
\text { Sciences, UC Merced }\end{array}$ & $\begin{array}{l}\text { Applied mathematician who is work in } \\
\text { solving inverse problems using numerical } \\
\text { analysis. Currently involving in light } \\
\text { transport inverse problems. }\end{array}$ \\
\hline 3 & $\begin{array}{l}\text { Dr. Edmund Lau } \\
\text { (Ph.D. UC Santa Barbara) }\end{array}$ & $\begin{array}{l}\text { Physical and Life } \\
\text { Sciences Directorate, } \\
\text { LLNL }\end{array}$ & $\begin{array}{l}\text { Computational Biologist who uses massively } \\
\text { parallel supercomputers to simulate } \\
\text { biomolecules }\end{array}$ \\
\hline 4 & $\begin{array}{l}\text { Dr. Felice Lightstone } \\
\text { (Ph.D. UC Santa Barbara) }\end{array}$ & $\begin{array}{l}\text { Physical and Life } \\
\text { Sciences Directorate, } \\
\text { LLNL }\end{array}$ & $\begin{array}{l}\text { Computational Biologist who uses massively } \\
\text { parallel supercomputers to simulate } \\
\text { biomolecules }\end{array}$ \\
\hline 5 & $\begin{array}{l}\text { Prof. David Ojcius } \\
\text { (Ph.D. UC Berkeley) }\end{array}$ & $\begin{array}{l}\text { School of Natural } \\
\text { Sciences, UC Merced }\end{array}$ & $\begin{array}{l}\text { Cell biologist who studies mechanisms of } \\
\text { cell-to-cell pathogen transmission; interested } \\
\text { in modeling microscopic and macroscopic } \\
\text { pathogen transmission }\end{array}$ \\
\hline 6 & $\begin{array}{l}\text { Asst. Prof. Matthew Meyer } \\
\text { (Ph.D. Texas A\&M) }\end{array}$ & $\begin{array}{l}\text { School of Natural } \\
\text { Sciences, UC Merced }\end{array}$ & $\begin{array}{l}\text { Organic chemist who uses a mix of } \\
\text { experiment and molecular modeling for drug } \\
\text { discovery. }\end{array}$ \\
\hline 7 & $\begin{array}{l}\text { Asso. Prof. Monica Medina } \\
\text { (Ph.D. Univ. Florida) }\end{array}$ & $\begin{array}{l}\text { School of Natural } \\
\text { Sciences, UC Merced }\end{array}$ & $\begin{array}{l}\text { Genomicist who uses experimental and } \\
\text { computational methods to study } \\
\text { phylogenetics and organelle genome } \\
\text { evolution of marine invertebrate animals and } \\
\text { the genomics of coral-zooxanthellae } \\
\text { symbioses in Caribbean reefs. }\end{array}$ \\
\hline 8 & $\begin{array}{l}\text { Asst. Prof. Jennifer Manilay } \\
\text { (Ph.D. Harvard) }\end{array}$ & $\begin{array}{l}\text { School of Natural } \\
\text { Sciences, UC Merced }\end{array}$ & $\begin{array}{l}\text { Developmental biologist studying } \\
\text { mechanisms controlling cell fate decisions in } \\
\text { the immune system; interested in building } \\
\text { mathematical models of the development of } \\
\text { T lymphocytes. }\end{array}$ \\
\hline 9 & $\begin{array}{l}\text { Asst. Prof. Mayya Tokman } \\
\text { (Ph.D. Caltech) }\end{array}$ & $\begin{array}{l}\text { School of Natural } \\
\text { Sciences, UC Merced }\end{array}$ & $\begin{array}{l}\text { Applied and computational mathematician } \\
\text { who primarily studies solar plasma physics } \\
\text { and combustion, but is interested in applying } \\
\text { her mathematical methods to biophysical } \\
\text { processes. }\end{array}$ \\
\hline 10 & $\begin{array}{l}\text { Asst. Prof. Shawn Newsam } \\
\text { (Ph.D. UC Santa Barbara) }\end{array}$ & $\begin{array}{l}\text { School of } \\
\text { Engineering, UC } \\
\text { Merced }\end{array}$ & $\begin{array}{l}\text { Computational Scientist who is working on } \\
\text { Bioinformatics - data mining and data } \\
\text { visualization }\end{array}$ \\
\hline
\end{tabular}




\begin{tabular}{|c|c|c|c|}
\hline 11 & $\begin{array}{l}\text { Asst. Prof. Miriam Barlow } \\
\text { (Ph.D. Univ. of Rochester) }\end{array}$ & $\begin{array}{l}\text { School of Natural } \\
\text { Sciences, UC Merced }\end{array}$ & $\begin{array}{l}\text { Evolutionary Biologist: studying evolution } \\
\text { of antibiotic resistance }\end{array}$ \\
\hline 12 & $\begin{array}{l}\text { Asst. Prof. Ajay Gopinathan } \\
\text { (Ph. D. Univ. of Chicago) }\end{array}$ & $\begin{array}{l}\text { School of Natural } \\
\text { Sciences, UC Merced }\end{array}$ & $\begin{array}{l}\text { Computational Biophysicist: studying cell } \\
\text { membrane dynamics }\end{array}$ \\
\hline 13 & $\begin{array}{l}\text { Asst. Prof. Jason Raymond } \\
\text { (Ph. D. Arizona State) }\end{array}$ & $\begin{array}{l}\text { School of Natural } \\
\text { Sciences, UC Merced }\end{array}$ & $\begin{array}{l}\text { Bioinformatician: integrating computational } \\
\text { and experimental approaches to understand } \\
\text { the origin, evolution, and function of these } \\
\text { molecular underpinnings of life. }\end{array}$ \\
\hline 14 & $\begin{array}{l}\text { Asst. Prof. Linda Hirst } \\
\text { (Ph. D. Manchester } \\
\text { University) }\end{array}$ & $\begin{array}{l}\text { School of Natural } \\
\text { Sciences, UC Merced }\end{array}$ & $\begin{array}{l}\text { Biophysicist: Soft condensed matter physics } \\
\text { including membrane biophysics, protein } \\
\text { network assembly and novel liquid crystal } \\
\text { materials and composites. }\end{array}$ \\
\hline 15 & $\begin{array}{l}\text { Asst. David Ardell } \\
\text { (Ph. D. Stanford University) }\end{array}$ & $\begin{array}{l}\text { School of Natural } \\
\text { Sciences, UC Merced }\end{array}$ & $\begin{array}{l}\text { Biinformatician: investigating gene } \\
\text { expression mechanisms and genomes. Our } \\
\text { aim is to discover new principles governing } \\
\text { information flow in living cells. Our goal is } \\
\text { to better understand the nature and origin of } \\
\text { life, particularly growth, stress-resistance, } \\
\text { aging, and disease. }\end{array}$ \\
\hline 16 & $\begin{array}{l}\text { Asst. Carolin Frank } \\
\text { (Ph.D. Uppsala University, } \\
\text { Sweden) }\end{array}$ & $\begin{array}{l}\text { School of Natural } \\
\text { Sciences, UC Merced }\end{array}$ & $\begin{array}{l}\text { Genomicist Studying microbes that live in } \\
\text { close association with animals and plants } \\
\text { Environmental and symbiotic microbiology } \\
\text { and genomics }\end{array}$ \\
\hline 17 & $\begin{array}{l}\text { Prof. Maria Pallavicini } \\
\text { (Ph.D. Univ. Utah) }\end{array}$ & $\begin{array}{l}\text { School of Natural } \\
\text { Sciences, UC Merced }\end{array}$ & $\begin{array}{l}\text { Cell biologist who performs quantitative } \\
\text { proteomics measurements related to cell fate } \\
\text { decisions }\end{array}$ \\
\hline
\end{tabular}




\section{II - CCB Summer Research Internship Program Participants}

\begin{tabular}{|c|c|c|}
\hline Name & Major & Undergraduate Institution \\
\hline \multicolumn{3}{|c|}{2006 Cohort } \\
\hline Alaena Alilin & Applied Mathematics & UC Merced \\
\hline Ritu Bhardwaj & Biological Sciences & UC Merced \\
\hline Shay Mansoor & Biological Sciences & UC Merced \\
\hline Mahndisa Rigmaiden & Physics & San Francisco State Univ. \\
\hline Kiran Aulakh & Biological Sciences & UC Merced \\
\hline Zer Vue & Biological Sciences & UC Merced \\
\hline Demseen Danielson & Biological Sciences & UC Merced \\
\hline \multicolumn{3}{|c|}{2007 Cohort } \\
\hline Sarah Montoy & Biological Sciences & UC Merced \\
\hline Haruka Swendsen & Biological Sciences & UC Merced \\
\hline Alyssa Krepela & Biological Sciences & UC Merced \\
\hline Inderae Kaur & Biological Sciences & UC Merced \\
\hline Claudia Velázquez & Biological Sciences & UC Merced \\
\hline Angelina Velázquez & Biological Sciences & UC Merced \\
\hline William St. Clair & Applied Math & UC Merced \\
\hline Julia Zhou & Cognitive Science & UC Merced \\
\hline \multicolumn{3}{|c|}{2008 Cohort } \\
\hline Allison Tobin & Biological Sciences & UC Merced \\
\hline Jo-Anne Rodriguez & Biological Sciences & UC Merced \\
\hline Chi Ying Lau & Bioengineering & UC Merced \\
\hline K Chico & Bioengineering & UC Merced \\
\hline Heather Orrell & Biological Sciences & UC Merced \\
\hline Amanda Fox & Biological Sciences & UC Merced \\
\hline Max Koobatian & Chemistry & UC Merced \\
\hline Chai Lor & Bioengineering & UC Merced \\
\hline Alaena Alilin & Applied Mathematics & UC Merced \\
\hline \multicolumn{3}{|c|}{2009 Cohort } \\
\hline Jonathan Dalisay & Biological Sciences & UC Merced \\
\hline Anupriya Dayal & Biostatistics & UC Berkeley \\
\hline Yogesh Narayanan & Biological Sciences & UC Merced \\
\hline Aparna Pasumarthi & Biological Sciences & UC Merced \\
\hline Kristopher Plambeck & Biological Sciences & UC Merced \\
\hline Kristin Tanyag & Biological Sciences & UC Merced \\
\hline Thompson Lu & Biological Sciences & UC Merced \\
\hline Drew Tilley & Mechanical Engineering & UC Merced \\
\hline Cristal Yee & Biological Sciences & UC Merced \\
\hline \multicolumn{3}{|c|}{2010 Cohort } \\
\hline Cierra D. Coffman & Chemistry & Fresno State University \\
\hline Heath S. Watanabe & Liberal Arts & Soka University of America \\
\hline Michael Swain & Cognitive Science & UC Merced \\
\hline Anh Nguyen & Biological Sciences & UC Merced \\
\hline Thu Vo & Biological Sciences & UC Merced \\
\hline Thin Vwai & Biological Sciences & UC Merced \\
\hline Erick Aitchison & Biological Sciences & UC Merced \\
\hline Ashley Graham & Biological Sciences & UC Merced \\
\hline David Johnston & Biological Sciences & UC Merced \\
\hline Corinne Gray & Physics & UC Merced \\
\hline Lauren Edwards & Biological Sciences & UC Merced \\
\hline
\end{tabular}




\begin{tabular}{|c|c|c|}
\hline Name (Period) & Major and Institution & Research Project \\
\hline $\begin{array}{l}\text { Jo-Anne Rodriguez } \\
\text { (July 2008-June 2009) }\end{array}$ & $\begin{array}{l}\text { Biological Sciences } \\
\text { UC Merced }\end{array}$ & Modeling carbon nanotube \\
\hline $\begin{array}{l}\text { Alaena Alilin } \\
\text { (July 2008-June 2009) }\end{array}$ & $\begin{array}{l}\text { Applied Mathematics } \\
\text { UC Merced }\end{array}$ & Modeling carbon nanotube \\
\hline $\begin{array}{l}\text { Demseen Danielson } \\
\text { (August, } 2006 \text { - December 2008) }\end{array}$ & $\begin{array}{l}\text { Biological Sciences } \\
\text { UC Merced }\end{array}$ & $\begin{array}{l}\text { Modeling modified nucleic } \\
\text { acids }\end{array}$ \\
\hline $\begin{array}{l}\text { Drew Tilley } \\
\text { (July } 2009 \text { - Present) }\end{array}$ & $\begin{array}{l}\text { Mechanical Engineering } \\
\text { UC Merced }\end{array}$ & $\begin{array}{l}\text { Modeling modified nucleic } \\
\text { acids }\end{array}$ \\
\hline $\begin{array}{l}\text { Erick Aitchison } \\
\text { (July } 2010 \text { - Present) }\end{array}$ & $\begin{array}{l}\text { Biological Sciences } \\
\text { UC Merced }\end{array}$ & Unstructured Protein \\
\hline $\begin{array}{l}\text { Heath S. Watanabe } \\
\text { (July } 2010 \text { - August 2010) }\end{array}$ & $\begin{array}{l}\text { Liberal Arts } \\
\text { Soka University of America }\end{array}$ & Modeling carbon nanotube \\
\hline
\end{tabular}

\section{IV - CCB Graduate Research Associates}

\begin{tabular}{|l|l|l|}
\hline Name & Major and Institution & \multicolumn{1}{|l|}{ Research Project } \\
Joshua Phillips & $\begin{array}{l}\text { Computer Science, UC } \\
\text { Merced }\end{array}$ & $\begin{array}{l}\text { New tools for describing the dynamics of unstructured } \\
\text { proteins }\end{array}$ \\
\hline John Loffeld & Applied Math, UC Merced & Efficient computational models for bio-applications \\
\hline Jane Hyo Jin Lee & Applied Math, UC Merced & $\begin{array}{l}\text { Molecular dynamics simulations biomembrane to } \\
\text { enable continuum mathematical models }\end{array}$ \\
\hline Heinz D. Falenski & $\begin{array}{l}\text { Quantitative and System } \\
\text { Biology, UC Merced }\end{array}$ & Population modeling of ecosystems \\
\hline Matt Pettengill & $\begin{array}{l}\text { Quantitative and System } \\
\text { Biology, UC Merced }\end{array}$ & $\begin{array}{l}\text { Pilot project to study possibility of lyme disease model } \\
\text { for Yosemite National Park }\end{array}$ \\
\hline Igor Goncharenko & Physics, UC Merced & Optimizing kinetics in biological processes \\
\hline Markus Allesch, & $\begin{array}{l}\text { Graz University of } \\
\text { Technology, Austria } \\
\text { Research performed at } \\
\text { LLNL) }\end{array}$ & $\begin{array}{l}\text { First principles molecular dynamics modeling of } \\
\text { benzene water mixtures (2006-2007) }\end{array}$ \\
\hline
\end{tabular}




\begin{tabular}{|c|c|c|c|}
\hline \multicolumn{2}{|r|}{ Name } & Affiliated period & \multirow{2}{*}{$\begin{array}{l}\text { Research Project } \\
\text { Computational Chemist who is conducting } \\
\text { molecule dynamics and quantum chemical } \\
\text { simulations of biomolecular systems }\end{array}$} \\
\hline 1 & $\begin{array}{l}\text { Dr. Edmond Lau } \\
\text { (Ph.D. UCSB) }\end{array}$ & $\begin{array}{l}\text { November, } 2004 \text { - August, } \\
2010\end{array}$ & \\
\hline 2 & $\begin{array}{l}\text { Dr. Pedro González- } \\
\text { Rodríguez } \\
\text { (Ph.D. Universidad } \\
\text { Carlos III de Madrid) }\end{array}$ & May, 2006 - December 2008 & $\begin{array}{l}\text { Applied mathematician who is work in } \\
\text { solving inverse problems using numerical } \\
\text { analysis. Currently involving in light } \\
\text { transport inverse problems. }\end{array}$ \\
\hline 3 & $\begin{array}{l}\text { Dr. Hélène Morlon } \\
\text { (Ph.D. U. Bordeaux I, } \\
\text { France) }\end{array}$ & November, 2005 - January, 2008 & $\begin{array}{l}\text { Applied mathematician who is working on } \\
\text { mathematical models of biological diversity } \\
\text { and patterns in the spatial distribution and } \\
\text { abundance of species. }\end{array}$ \\
\hline 4 & $\begin{array}{l}\text { Dr. John Tamaresis } \\
\text { (Ph.D. UC Davis) }\end{array}$ & December, 2004 - August, 2006 & $\begin{array}{l}\text { Applied and computational mathematician } \\
\text { who is developing partial differential } \\
\text { equation models of stem cell differentiation } \\
\text { and transport between different } \\
\text { compartments }\end{array}$ \\
\hline 5 & $\begin{array}{l}\text { Dr. Scott Hotton } \\
\text { (Ph.D. UC Santa Cruz) }\end{array}$ & December, 2004 - April, 2006 & $\begin{array}{l}\text { Applied mathematician with expertise in } \\
\text { dynamical systems and geometric topology } \\
\text { who is studying the population dynamics of } \\
\text { developing cell populations }\end{array}$ \\
\hline
\end{tabular}




\section{VI - CCB Publications Between 2006 and 2010}

1. A. D. Kim, C. Hayakawa and V. Venugopalan, "Estimating tissue optical properties by use of the Born approximation of the transport equation," OPTICS LETTERS 31, 1088, (2006)

2. A. D. Kim and J. C. Schotland, "Self-consistent scattering theory for the radiative transport equation,” Journal of the Optical Society of America A 23, 596-602 (2006).

3. A. D. Kim and M. Moscoso, "Radiative transport theory for optical molecular imaging,” Inverse Problems 22, 23-42 (2006).

4. M.E. Colvin, C.J. Cramer, C.E. Dykstra, J.H. Jensen, S. Krimm, J.-L. Rivail, A.J. Thakkar and M. Yáñez, "Molecular quantum mechanics to biodynamics: Essential connections” Journal of Molecular Structure: THEOCHEM 764 (2006) 1-8

5. S. Hotton and M.E. Colvin, (2007) "Analytic formulas for discrete stochastic models of cell populations with both differentiation and de-differentiation”, Journal of Theoretical Biology 245: 610-626.

6. P. González-Rodríguez, A. D. Kim and M. Moscoso, "Reconstructing a thin absorbing obstacle in a half space of tissue," Journal of the Optical Society of America A 24, 3456-3466 (2007) [Also cited in The Virtual Journal for Biomedical Optics 2:12 (2007) and Virtual Journal of Biological Physics Research 14:12 (2007)].

7. A. D. Kim and P. Tranquilli, "Numerical solution of a boundary value problem for the Fokker-Planck equation with variable coefficients," Journal of Quantitative Spectroscopy and Radiative Transfer 109, 727-740 (2007).

8. P. González-Rodríguez and A. D. Kim, "Light propagation in two layer tissues with an irregular interface," Journal of the Optical Society of America A 25, 64-73 (2007) [Also cited in The Virtual Journal of Biological Physics Research 15: 3 (2008)].

9. P. González-Rodríguez and A. D. Kim, "Light propagation in tissues with forwardpeaked and large-angle scattering,” Applied Optics 47, 2599-2609 (2008).

10. Morlon, H., Chuyong, G., Condit, R., Hubbell, S., Kenfack, D., Thomas, D., Valencia, R., Green, J. "A general framework for the distance-decay of similarity in ecological communities.” Ecology Letters 11, (2008).

11. V.V. Krishnan, E.Y. Lau, J. Yamada, D.P. Denning, S.S. Patel, M.E. Colvin and M.F. Rexach Intra-molecular Cohesion of Coils Mediated by Phenylalanine-Glycine Motifs in the Natively Unfolded Domain of a Nucleoporin PLOS Computational Biology 4: e1000145, doi:10.1371/journal.pcbi.1000145, (2008)

12. J.L. Phillips, E.Y. Lau, M.E. Colvin, and S. Newsam (2008) Analyzing Dynamical Simulations of Intrinsically Disordered Proteins Using Spectral Clustering IEEE 
Workshop on Computational Structural Bioinformatics Workshop pg. 17-24 doi: 10.1109/BIBMW.2008.4686204, (2008).

13. I. Goncharenko and A. Gopinathan, "Optimal Yield Rates in Enzymatic Reactions with Undesirable Intermediate States", Proceedings of the International Conference on Computational Biology (WCECS 2008), p24 (2008)

14. E.Y. Lau, J.L. Phillips and M.E. Colvin, "Molecular dynamics simulations of highly charged green fluorescent proteins” Molecular Physics 107, 1233-1241 (2009).

15. P. González-Rodríguez and A. D. Kim, "Reflectance optical tomography in epithelial tissues,” Inverse Problems 25, 015001 (2009).

16. J. Clark, P. González-Rodríguez and A. D. Kim, "Using polarization to find a source in a turbid medium," Journal of the Optical Society of America A 26, 1129-1138 (2009).

17. P. González-Rodríguez and A. D. Kim, "Comparison of light scattering models for diffuse optical tomography,” Optics Express 17, 8756-8774 (2009).

18. I. Goncharenko and A. Gopinathan, "Optimal Kinetics for Chaperonin Assisted Protein Folding”, IAENG Transactions on Engineering Technologies 2, p13 (2009) 


\section{VII - List of CCB Distinguished Speakers}

\begin{tabular}{|c|c|}
\hline \multicolumn{2}{|r|}{ Speakers } \\
\hline \multicolumn{2}{|r|}{ AY 2005-2006 } \\
\hline 1 & $\begin{array}{l}\text { Prof. Stephen Mayo } \\
\text { Professor of Biology and Chemistry, California Institute of Technology } \\
\text { Title: Modulation and De Novo Design of Protein-Protein Interactions }\end{array}$ \\
\hline 2 & $\begin{array}{l}\text { Prof. Adam Arkin } \\
\text { Professor of Bioengineering and Chemistry, University of California, Berkeley } \\
\text { Title: Adversity, Diversity, and the Dynamics and Evolution of Cellular Networks: Case } \\
\text { studies from microbes to macrophage }\end{array}$ \\
\hline 3 & $\begin{array}{l}\text { Prof. Richard Lathrop } \\
\text { Professor of Information and Computer Science, University of California, Irvine } \\
\text { Title: Functional census of mutation sequence spaces: The example of p53 cancer } \\
\text { rescue mutants }\end{array}$ \\
\hline 4 & $\begin{array}{l}\text { Dr. Supratim Sengupta } \\
\text { Dalhousie University, Canada } \\
\text { Title: Evolution of the Genetic Code }\end{array}$ \\
\hline 5 & $\begin{array}{l}\text { Prof. Niles Pierce } \\
\text { Professor of Applied and Computational Mathematics and Bioengineering, CalTech } \\
\text { Title: Computational Analysis and Design of Nucleic Acid Devices }\end{array}$ \\
\hline 6 & $\begin{array}{l}\text { Dr. Nagiza Samatova } \\
\text { Senior Investigator, Oak Ridge National Laboratory } \\
\text { Title: Computational Algorithms and Software Tools for Quantitative Shotgun Proteomics }\end{array}$ \\
\hline 7 & $\begin{array}{l}\text { Dr. Jianhua Xing } \\
\text { Lawrence Livermore National Laboratory } \\
\text { Title: Modeling Protein Motors }\end{array}$ \\
\hline \multicolumn{2}{|r|}{ AY 2006-2007 } \\
\hline 1 & $\begin{array}{l}\text { Prof. Mathieu Blanchette } \\
\text { Department of Computer Science, McGill University (Canada) } \\
\text { Title: Whole-genome comparative and regulatory genomics }\end{array}$ \\
\hline 2 & $\begin{array}{l}\text { Emeritus Prof. Barry Hall } \\
\text { Department of Biology, University of Rochester }\end{array}$ \\
\hline
\end{tabular}




\begin{tabular}{|c|c|}
\hline & Title: 2-day Workshops for Phylogeny \\
\hline 3 & $\begin{array}{l}\text { Prof. Bruce Rannala } \\
\text { Section of Evolution and Ecology, University of California, Davis } \\
\text { Title: Inferring Speciation Times under an Episodic Molecular Clock }\end{array}$ \\
\hline 4 & $\begin{array}{l}\text { Prof. Ping Ma } \\
\text { Department of Statistics, University of Illinois at Urbana-Champaign } \\
\text { Title: Statistical assessment of the global regulatory role of histone acetylation in } \\
\text { Saccharomyces cerevisiae }\end{array}$ \\
\hline 5 & $\begin{array}{l}\text { Dr. P. Thomas Vernier } \\
\text { Information Sciences Institute, University of Southern California } \\
\text { Title: Biomolecular Manipulations With Nanosecond Pulsed Electric Fields - In Cells and } \\
\text { In Silico }\end{array}$ \\
\hline 6 & $\begin{array}{l}\text { Prof. Andrej Sali } \\
\text { Dept. of Biopharmaceutical Sciences \& Pharmaceutical Chemistry } \\
\text { California Institute for Quantitative Biomedical Research } \\
\text { University of California, San Francisco } \\
\text { Title: Modeling the structures of proteins and macromolecular assemblies }\end{array}$ \\
\hline 7 & $\begin{array}{l}\text { Prof. Kevin Karplus } \\
\text { Department of Biomolecular Engineering, University of California, Santa Cruz } \\
\text { Title: Origami with strings: protein folding by computer }\end{array}$ \\
\hline 8 & $\begin{array}{l}\text { Dr. Timothy Isogro } \\
\text { Theoretical and Computational Biophysics, University of Illinois, Urbana-Champaign } \\
\text { Title: The Association of Nuclear Pore FG-repeat Proteins and Transport Receptors }\end{array}$ \\
\hline 9 & $\begin{array}{l}\text { Prof. Jennifer W. Weller } \\
\text { Dept of Bioinformatics and Computational Biology, George Mason University } \\
\text { Title: Assessing Microarray Measurements on the Basis of Probe Parameterss }\end{array}$ \\
\hline 10 & $\begin{array}{l}\text { Prof. Michael J. Sanderson } \\
\text { Department of Ecology and Evolutionary Biology, University of Arizona } \\
\text { Title: Prospects for building the evolutionary tree of life from large sequence databases }\end{array}$ \\
\hline
\end{tabular}




\begin{tabular}{|c|l|}
\hline $\mathbf{1}$ & \multicolumn{1}{|c|}{ AY 2007-2008 } \\
\hline $\mathbf{2}$ & $\begin{array}{l}\text { Prof. Professor John Quackenbush } \\
\text { Dana-Farber Cancer Institute, Harvard School of Public Health } \\
\text { Title: Whole Stochasticity and Networks in Genomic Data }\end{array}$ \\
\hline & $\begin{array}{l}\text { Professor Eric Jakobsson } \\
\text { National Center for Supercomputing Applications at the University of Illinois }\end{array}$ \\
\hline
\end{tabular}

